\title{
Effects of Inflation and Exchange Rates on Stock Prices of PT Bank Negara Indonesia (Persero) Tbk
}

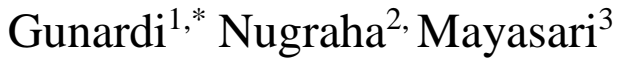

\author{
${ }^{1}$ Universitas Pendidikan Indonesia \\ ${ }^{2}$ Universitas Pendidikan Indonesia \\ ${ }^{3}$ Universitas Pendidikan Indonesia \\ *Corresponding author. Email: gunardi@upi.edu
}

\begin{abstract}
This study aims to examine the effect of macroeconomic factors, namely the exchange rate and inflation, on the stock prices of PT Bank Negara Indonesia. This research is based on Kwofie and Ansah's study, which states that most investors do not consider the macroeconomic influence on stock prices. Previous research showed an influence between macroeconomic factors on stock prices. This study uses inflation and exchange rate data found at Bank Indonesia, while the stock price of PT. Bank Negara Indonesia, which is on the Indonesia Stock Exchange for the period 2009-2019, the data is tested using multiple regressions using eviews 10. The results showed that the exchange rate and inflation affect the stock prices at PT Bank Negara Indonesia. This indicates that there is adjusting to the theory of Arbitrage Pricing Theory (APT).
\end{abstract}

Keywords: Inflation, Exchange Rate, Stock Price.

\section{INTRODUCTION}

Most investors invest in stocks with the idea of maximizing their investment returns. However, this decision was made without considering the influence of macroeconomic factors such as inflation and the exchange rate on the stock prices of public companies [1]. Low et al. (2018) argues that the stock market has a vital position in developing a country's economy [2]. According to them, the stock market serves as a source for mobilizing domestic resources for productive investment. They suspect that to carry out this role, and the stock market must have an authentic influence on the economy.

The stock price is considered the primary indicator for economic activity and can determine economic factors that influence the economic situation [3][4]. Mean-while, stock prices are dominantly influenced by financial factors [5]. However, macroeconomic factors cannot be ruled out in understanding economic conditions [6]. From various macroeconomic fac-tors, inflation is the most consistent factor in various countries influencing stock prices [7].
Inflation fluctuations have a small long-term im-pact on stock returns listed on the Stock Exchange because monetary is not neutral. Previous research shows that stock prices are influenced by short-term inflation factors [8];[9]. In this context, various studies show inflation has a positive or negative influence on stock prices depending on the theory used in research. Gordon's growth model (1962) shows that economic growth directly affects stock prices with the expectation of dividend returns inversely proportional to the return on capital. Based on that, inflation has a positive influence on stock prices in two ways: First, a decrease in the monetary level can improve the economy with the positive impact of inflation on dividend growth. Second, a monetary expansion that aims to reduce liability returns will impact increasing demand for equity, which will cause most investors to reduce the expected rate of return on equity [10].

An important macroeconomic factor in a country is the exchange rate. In a theoretical or practical study, the effect of exchange rates on stock prices has been carried out comprehensively. Previous studies have shown the relationship between stock prices theoretically and exchange rates have two forms. Dornbusch and Fischer 
(1980), first, suggest a change in the exchange rate model that is "value-oriented", because changes in the exchange rate of a country's currency in the previous period can affect the country's competitiveness in the international economy and also affect the trade balance so that it can affect real income and output [11]. Share prices are defined as the value of the company's future cash flows that react to changes in exchange rates to affect the future income, interest rates, current investments, and consumption decisions. Gavin (1989) argues that innovation in the stock market influences aggregates demand through wealth and liquidity effects so that innovation in the stock market affects the demand for foreign currencies and the exchange rate [12]. Second, Branson (1983) presents a "stock-oriented" exchange rate model, which sees the ex-change rate equating supply and demand for shares [13]. This approach can determine the dynamics of ex-change rates by providing an essential role in calculating capital. This is based on the view that the value of financial assets is determined by the present value of future cash flows, the expected relative value of currencies playing a massive role in the movement of stock prices. Therefore, changes in stock prices have a two-way effect on the dynamics of the exchange rate.

Based on the explanation, it seems that inflation and exchange rate are macroeconomic factors that have a consistent influence on a company's stock price because these two factors will be felt directly by the company. Thus, an investor must consider the inflation factor and the country's exchange rate to invest in.

Inflation is defined as an ongoing and sustainable process of raising general prices continuously. It can be said as a common concern for any government because it serves as a proxy to determine how well the economy is running [14]. According to Ibrahim and Agbaje (2013), the inflation rate is increasingly unstable even though several policies and hard efforts are made by the government to control its values to be a satisfactory single source of stationary numbers [15]. They also argue that factors such as income, high nominal wages, income fluctuations, and debt payments can largely influence inflation in an economy.

Kitatia, Zablonb, and Maithya (2015) conducted a study in Kenya in the period 2008-2012, stating that the macro factors that formed stock prices, namely inflation had a negative effect, interest rates had a negative effect, and the exchange rate had a negative effect [16]. Maysami and Koh (2000), in their research, showed that high imports and exports in the Singapore economy resulted in the strengthening of the domestic currency, as well as being able to re-duce the cost of imported inputs so that local producers would be more competitive in the international economy [17]. Maysami, et al. also explain that the firm Singapore dollar limits import inflation and is considered favorable news by the Singapore stock market, resulting in positive returns [18]. Gan et al. conducted a study in New Zealand, the period 19902003, stating that the macro factors that shape stock prices are inflation has a negative effect, interest rates have a negative effect, the exchange rate has a positive effect [19].

The exchange rate is the price of a country's currency, measured in other currencies. Exchange rates have a crucial role in spending decisions. This is because the exchange rate allows prices from various countries into the same language [20]. Mishkin (2009) states that the ex-change rate is the price of a currency compared to the prices of other currencies. Mishkin also stated that understanding the exchange rate's behavior in a shortterm context can be done by understanding that the exchange rate is the price of domestic assets contained in foreign assets because the price set in foreign assets can affect the exchange rate [21]. Another more general way to find out the exchange rate in the short term is to use an asset market approach that relies on asset demand theory [21].

Other studies related to the effect of exchange rates on stock prices have been widely studied, among which the results show a difference. Research conducted by Bahmani-Oskooee and Sohrabian (1992) shows that there is a two-way relationship be-tween stock prices and the dollar exchange rate [22]. Chiang and Yang (2003) show that stock returns and currency values positively correlate with nine stock markets in Asia [23]. Wu (2000) shows that the exchange rate of the Singapore dollar influences stock prices [24]. Likewise, with the results of research conducted by Ramasamy and Yeung (2002) that there is a relation-ship between foreign exchange and the stock market that has implications for capital control during the period 1995-2001 in six Asian countries [25].

Richard A. Ajayi and Mbodja Mougoue (1996) researched the countries of Canada, France, Germany, Italy, Japan, Netherlands, UK, US in the study period from 1985 to 1991 , stating that the exchange rate has a one-way relationship in the short and long term length of stock prices [26]. Aggarwal (1981) found that U.S. stock prices and dollar trading had a posi-tive influence [27]. In contrast, Soenen and Hennigar (1988) found a negative influence between the US stock indexes and the dollar exchange rate [28]. Donnelly and Sheehy (1996) showed a significant relationship between the exchange rate and market value in the United Kingdom[29].

The results of research conducted by Mads Asprem (1989) in France, Germany, Italy, Switzer-land, and the U.K. in the study period 1968 to 1984 stated that the exchange rate has a one-way relation-ship to stock prices [30]. The research conducted by Kim (2003) in the United States in the study period from 1974 to 1998 stated that the exchange rate has a one-way relationship to stock prices [31]. Pan et al. (2007) examined the effect of exchange rates and share prices in seven East Asian countries, not including China [32]. Also, Yau and Nieh 
(2009) examined the effect of the Taiwan dollar exchange rate on the Japanese Yen on share prices in Japan and Taiwan [33]. The results of the study showed a long-term balance.

\section{METHODS}

This study uses independent variables and de-pendent variables. An Independent variable is an in-dependent variable whose existence is not influenced by other variables. The independent variables in this study are inflation (X1) and exchange rate (X2). Meanwhile, the dependent variable is a variable whose existence is not free to be influenced by other variables. The dependent variable in this study is the Stock Price (Y).

Secondary data used are previously available from other parties collected from various documents, literature, articles, and scientific papers confirmed as authentic. Secondary data is used to consider that this data has data validity guaranteed by other parties, so it is suitable for research. The data collected are the exchange rates in Indonesia from January 2009 to December 2019. The sample data used is monthly data, so the amount of data used is 132 data. With data sources including:

a. The stock prices taken from the monthly data of PT Bank Negara Indonesia (Persero) Tbk in the Indonesia Stock Exchange.

b. The inflation and exchange rate variables taken from monthly data of Bank Indonesia.

Data analysis uses descriptive quantitative re-search results that show the influence or not, then analyzed descriptively with comparisons in developed countries and other emerging markets. The data analysis technique uses regression tests with Eviews 9 application.

\section{RESULTS AND DISCUSSION}

Scalar variables and physical constants should be The research data shows that Indonesia's inflation rate during 2009-2019 shows inflation control stability. However, in January 2009, Indonesia's inflation rate was $9.17 \%$ which was the most considerable inflation rate for the last ten years, and from July 2013 to January 2014, Indonesia's inflation was above $8 \%$, which is a difficult time for Indonesia. However, overall, Indonesia's inflation rate shows stability in $3 \%$ to $4 \%$.

Inflationary conditions that show stability, in contrast to the Rupiah against the Dollar, in January 2009 the Rupiah exchange rate was 11,335 , the figure showed a continuous decline until it was at 8,537 in May 2011, but after that, the exchange rate trend continued to experience the increase to the highest number was in October 2018 of 15,227 .

PT Bank Negara Indonesia's stock price from 2009 to 2019 showed a continuous upward trend, at the beginning of January 2009 amounting to 770, until December 2019 amounting to 7,925 . The data obtained by researchers conducted a multiple regression test using eviews 10 to find the effect of inflation and the exchange rate on PT Bank Negara Indonesia's stock prices during 2009-2019.

Table 1. Multiple regression test

\begin{tabular}{|l|c|l|l|l|}
\hline \multicolumn{1}{|c|}{ Variable } & $\begin{array}{c}\text { Coefficien } \\
\text { t }\end{array}$ & Std. Error & t-Statistic & Prob. \\
\hline C & -2332.874 & 862.9767 & -2.703288 & 0.0078 \\
\hline INFLATION & -246.6148 & 70.63733 & -3.491282 & 0.0007 \\
\hline $\begin{array}{l}\text { EXCHANGE_RAT } \\
\text { E }\end{array}$ & 0.737453 & 0.060015 & 12.28772 & 0.0000 \\
\hline R-squared & 0.604714 & Mean dependent var & 5111.364 \\
\hline Adjusted R-squared & 0.598586 & S.D. dependent var & 2197.443 \\
\hline S.E. of regression & 1392.240 & Akaike info criterion & 17.33768 \\
\hline Sum squared resid & $2.50 \mathrm{E}+08$ & \multicolumn{2}{|l|}{ Schwarz criterion } & 17.40320 \\
\hline Log-likelihood & -1141.287 & \multicolumn{2}{|l}{ Hannan-Quinn criter. } & 17.36430 \\
\hline F-statistic & 98.67302 & Durbin-Watson stat & 0.157004 \\
\hline Prob(F-statistic) & 0.000000 & \multicolumn{3}{l}{} \\
\hline
\end{tabular}

Based on the regression test results, the results of carrying inflation and the exchange rate have a value of Porb. Below 0.05, which means inflation and exchange rates affect the stock price of PT. Bank Negara Indonesia. This condition also confirms that this study's results are in conformity with the theory of Arbitrage Pricing Theory (APT), which predicts the relationship between the return of a portfolio and the return of a single asset through a linear combination of many independent macroeconomic variables.

This study's results are similar to those of Kitatia, Zablonb, and Maithya's (2015) research in Kenya. Maysami and Koh's (2000) research in Singapore and Gan et al. (2006) conducted research in New Zealand, showing that inflation affects stock prices. In this condition, it seems that Gupta and Inglesi-Lotz (2012) view that inflation undoubtedly influences stock prices.

Related to the effect of exchange rates on stock prices, it seems to be following Aggarwal's (1981) and Soenen and Hennigar's (1988) research in the United States, Bahmani-Oskooee and Sohrabian's (1992), Ajayi et al.'s (1998), Chiang and Yang's (2003) researches in the Asian market, Wu's (2000) research in Singapore, Pan et al.'s (2007) research in East Asia, and Yau and Nieh's (2009) research in Taiwan which showed that exchange rates affect stock prices.

\section{CONCLUSIONS}

This study confirms that in Indonesia, macroeconomic factors such as the exchange rate and inflation influence stock prices. Macroeconomic factors 
are considered a signal by investors to invest in Indonesia. This study also has similarities with the results of research in other emerging market countries. It shows that inflation and the exchange rate are macroeconomic factors that consistently and undoubtedly influence stock prices in a company.

\section{REFERENCES}

[1] Kwofie, C., \& Ansah, R. K. (2018). A study of the effect of inflation and exchange rate on stock market returns in Ghana. International Journal of Mathematics and Mathematical Sciences, 1-8.

[2] Low, S. W., Albada, A., Chukari, N. A., \& Ghazali, N. A. (2018). Do stock market and banking sectors development promote innovation efficiency? International Journal of Managerial Finance.

[3] Weng, B., Lu, L., Wang, X., Megahed, F. M., \& Martinez, W. (2018). Predicting short-term stock prices using ensemble methods and online data sources. Expert Systems with Applications, 112, $258-273$.

[4] Rapach, D. E., and Weber, C.E., (2004). Financial Variables and the Simulated Out-of-Sample Forecastability of U.S. Output Growth Since 1985: An Encompassing Approach. Economic Inquiry, 42(4), 717-738.

[5] Masry, M., Sakr, A., \& Amer, M. (2018). Factors Affecting Dividend Policyin an Emerging Capital Markets (ECM's) Country: Theoratical and Empirical Study. International Journal of Economics, Finance and Management Sciences, 6(4), 139.

[6] Rapach, D., and Zhou, G., (2013). Forecasting Stock Returns. Handbook of Economic Forecasting, Volume 2A, Graham Elliott and Allan Timmermann (Eds.) Amsterdam: Elsevier, 328383.

[7] Peiro, A. (2016). Stock prices and macroeconomic factors: Some European evidence. International Review of Economics \& Finance, 41, 287-294.

[8] Valcarcel, V. J., (2012). The dynamic adjustments of stock prices to inflation disturbances. Journal of Economics and Business, 64, 117- 144.

[9] Borio, C., Gambacorta, L., \& Hofmann, B. (2017). The influence of monetary policy on bank profitability. International Finance, 20(1), 48-63.

[10] Antonakakis, N., Gupta, R., \& Tiwari, A. K. (2017). Has the correlation of inflation and stock prices changed in the United States over the last two centuries? Research in International Business and Finance, 42, 1-8.
[11] Dornbusch, R., Fischer, S., (1980). Exchange rates and the current account. Am. Econ. Rev. 70 (5), 960-971.

[12] Gavin, M., (1989). The stock market and exchange rate dynamics. J. Int. Money Finance 8 (2), 181200.

[13] Branson, W.H., (1983). Macroeconomic determinants of real exchange risk. In: Herring, R.J. (Ed.), Managing Foreign Exchange Risk. Cambridge University, Cambridge.

[14] Bateman, I. J., Mace, G. M., Fezzi, C., Atkinson, G., \& Turner, R. K. (2014). Economic analysis for ecosystem service assessments. In Valuing Ecosystem Services. Edward Elgar Publishing.

[15] Ibrahim, T.M dan Agbaje, O.M. (2013). The relationship betweenstock returns and inflation in nigeria," European ScientificJournal, 146-157.

[16] Kitatia, E., Zablonb, E., \& Maithyac, H. (2015). Effect of macro-economic variables on stock market prices for the companies quoted on the nairobi securities exchange in Kenya. International Journal of Sciences: Basic and Applied Research, 21(2), 235-263.

[17] Maysami, R. C., \& Koh, T. S. (2000). A vector error correction model of the Singapore stock market. International Review of Economics \& Finance, 9(1), 79-96

[18] Maysami, R. C., Howe, L. C., \& Rahmat, M. A. (2005). Relationship between macroeconomic variables and stock market indices: Cointegration evidence from stock exchange of Singapore's all-S sector Indices. Jurnal Pengurusan (UKM Journal of Management), 24

[19] Gan, C., Lee, M., Hwa, H., Yong, A., \& Zhang, J. (2006). Macroeconomic Variables and Stock Market Interactions: New Zealand Evidence. Investment Management and Financial Innovations, 3(4), 89-101.

[20] Krugman, P. R. (2012). International Economics New Myeconlab Access Card: Theory and Policy. Prentice Hall.

[21] Mishkin, F.S. (2011). Ekonomi Uang, Perbankan dan Pasar Keuangan. Buku 1. Edisi kedelapan. Jakarta: Salemba Empat.

[22] Bahmani-Oskooee, M., Sohrabian, A., (1992). Stock prices and the effective exchange rate of the Dollar. Appl. Econ. 24 (4), 459-464.

[23] Chiang, T.C., Yang, S.-Y., (2003). Foreign exchange risk premiums and time-varying equity 
market risks. Int. J. Risk Assess. Manage. 4 (4), 310-331.

[24] Wu, Y., (2000). Stock prices and exchange rates in a VEC model - the case of Singapore in the 1990s. J. Econ. Finance 24, 260-274.

[25] Ramasamy, B., Yeung, M., (2002). The relationship between exchange rates and stock price: implications for capital controls. Asia Pacific J. Econ. Business 6 (2), 46-60.

[26] Ajayi, R.A., Friedman, J., Mehdian, S.M., (1998). On the relationship between stock returns and exchange rates: tests of Granger causality. Global Finance J. 9 (2), 241-251.

[27] Aggarwal, R., (1981). Exchange rates and stock prices: a study of the US capital markets under floating exchange rates. Akron Business Econ. Rev. $12,7-12$.

[28] Soenen, L., Hennigar, E., (1988). An analysis of exchange rates and stock prices: the US experience between 1980 and 1986. Akron Business Econ. Rev. 19, 7-16.

[29] Donnelly, R., Sheehy, E., (1996). The share price reaction of U.K. exporters to exchange rate movements: an empirical study. J. Int. Business Stud. 27, 157-165
[30] Asprem, M. (1989). Stock prices, asset portfolios and macroeconomic variables in ten European countries. Journal of Banking and Finance, 13(4-5), 589-612.

[31] Kim, K. H. (2003). Dollar exchange rate and stock price: Evidence from multivariate cointegration and error correction model. Review of Financial Economics, 12(3), 301-313.

[32] Pan, M., Fok, R.C., Liu, Y.A., (2007). Dynamic linkages between exchange rates and stock prices: evidence from east Asian markets. Int. Rev. Econ. Finance 16, 503-520.

[33] Yau, H.Y., Nieh, C.C., (2009). Testing for cointegration with threshold effect between stock prices and exchange rates in Japan and Taiwan. Jpn. World Econ. 21, 292-300.

[34] Gordon, M. J., (1962). The investment, financing and valuation of the corporation. Homewood, IL: R.D. Irwin.

[35] Gupta, R., and Inglesi-Lotz, R., (2012). Macro Shocks and Real US Stock Prices with Special Focus on the "Great Recession". Applied Econometrics and International Development, 12 (2), 123-136. 